\title{
Article \\ Biomass Yield and Nutritive Value of Rye (Secale cereale L.) and Wheat (Triticum aestivum L.) Forages While Grazed by Cattle
}

\author{
Hannah N. Phillips ${ }^{1, *(\mathbb{C})}$, Bradley J. Heins ${ }^{1,2, * \mathbb{C}}$, Kathleen Delate ${ }^{3}$ and Robert Turnbull ${ }^{4}$ \\ 1 Department of Animal Science, University of Minnesota, 1364 Eckles Avenue, Saint Paul, MN 55108, USA \\ 2 West Central Research and Outreach Center, University of Minnesota, 46352 MN-329, Morris, MN 56267, USA \\ 3 Department of Agronomy and Horticulture, Iowa State University, 716 Farm House Lane, \\ Ames, IA 50011, USA; kdelate@iastate.edu \\ 4 Department of Horticulture, Iowa State University, 106 Horticulture Hall, Ames, IA 50011, USA; \\ turnbull@iastate.edu \\ * Correspondence: phil1149@umn.edu (H.N.P.); hein0106@umn.edu (B.J.H.)
}

Citation: Phillips, H.N.; Heins, B.J.; Delate, K.; Turnbull, R. Biomass Yield and Nutritive Value of Rye (Secale cereale L.) and Wheat (Triticum aestivum L.) Forages While Grazed by Cattle. Crops 2021, 1, 42-54. https:// doi.org/10.3390/crops1020006

Academic Editor: Gustavo A. Slafer

Received: 21 May 2021

Accepted: 21 June 2021

Published: 1 July 2021

Publisher's Note: MDPI stays neutral with regard to jurisdictional claims in published maps and institutional affiliations.

Copyright: (c) 2021 by the authors. Licensee MDPI, Basel, Switzerland. This article is an open access article distributed under the terms and conditions of the Creative Commons Attribution (CC BY) license (https:// creativecommons.org/licenses/by/ $4.0 /)$.

\begin{abstract}
Management strategies that integrate crops and livestock may lengthen the productivity of seasonal pasture systems in agroecological zones with short growing seasons. The biomass yield and nutritive value of fall-planted rye (Secale cereale L.) and wheat (Triticum aestivum L.) forages were determined in an integrated crop-livestock system under rotational cattle (Bos taurus L.) grazing and organic conditions for seven weeks during the spring and summer in Minnesota, USA. Rye yielded greater forage biomass at the beginning of the grazing interval, while wheat yielded greater forage biomass in the latter part of the grazing interval. In general, wheat had greater crude protein and less neutral detergent fiber, compared to rye, throughout the grazing interval. The predicted total tract

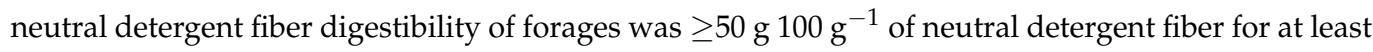
the first four weeks of the grazing interval, indicating high forage digestibility in immature forages. Results from this study suggest that rye may provide more forage biomass for grazing earlier in the spring at the expense of lower nutritive quality, compared to wheat. Thus, the biomass yield and nutritional value of rye and wheat forages vary during the grazing interval, which informs producers of grazing schedule modifications in order to meet the nutritional demands of cattle.
\end{abstract}

Keywords: cover crops; small grains; pasture forages; cattle grazing; organic; nutritive value; yield

\section{Introduction}

Maximizing forage production is important to organic cattle graziers since grazing represents a low-cost feeding strategy and since the USDA National Organic Program mandates that cattle must consume at least $\geq 30 \%$ of their dietary intake from pasture during the growing season [1]. Perennial grasses are the foundation of organic cattle pastures, which are typically productive between May and September in the upper Midwest of the United States of America (USA) [2]. However, opportunities to increase the seasonal grazing duration beyond the potential of perennial pastures may exist via utilizing alternative forages.

Previous research studies in the greater Midwestern region of the USA have suggested selecting cool-season annual grasses as a means to extend the grazing season and supplement existing perennial pasture systems, but cool-season annual grasses are seldom tested or evaluated under cattle grazing conditions [3-6]. Rotational grazing is superior to continuous grazing for cattle management on pasture due to its low environmental impact and positive effects on forage production $[7,8]$. Since cattle are selective grazers, forage nutritional quality may vary, following across the grazing interval under rotational stocking $[9,10]$. Therefore, it is necessary to investigate forages that are intended for grazing in realistic grazing systems with larger land areas, compared to the grazing of small forage plots. 
Methods of crop-livestock integration permit for additional opportunities for grazing that may arise that are beyond utilizing pastureland dedicated to cattle grazing, which may allow for grazing of alternative forage species in early spring or late autumn. It is a common practice in organic cropping systems to follow the summer crop harvest with an annual winter crop to protect the soil from erosion and nutrient leaching [11]. Winter annual crops that follow summer crops concurrently meet the soil building requirements of the USDA-National Organic Program (NOP) [12] and may provide a potential source of forage for cattle grazing in the early spring since these forages are adapted to grow in cooler temperatures. Since many organic cattle farmers simultaneously produce cereal grain crops within the same farming system, crop-livestock integration-a temporary pastureland that is integrated into a crop rotation [13] - may improve the feed efficiency of livestock production and lengthen the grazing season for cattle. Furthermore, producers integrating crops and livestock may also benefit from reduced feed transportation costs because cattle graze on livestock feed instead of a farmer purchasing feed off-farm to transport to the farm to feed cattle and improved soil quality [14]. Furthermore, crop-livestock integrated production practices may increase the value-added potential of the consequent animal products such as meat or milk [15]. Although this approach could improve farm profitability, perceived social obstacles of dominant farming systems, major crop markets, beginning farmers, and farmer networks restrain producers from fully adopting croplivestock practices [16]. A review by Lemaire et al. [17] on the potential benefits of modern crop-livestock systems identified a need for scientific research evaluating strategies to implement crops and livestock to ultimately support practicing farmers. Therefore, this research on integrating cattle and cover-cropping grazing systems contributes to filling a recognized knowledge gap in the applied grazing management of fall-planted cover crops for early spring grazing of cattle to extend the grazing season. The research will evaluate crop-livestock forages in beef and dairy cattle herds of the upper Midwest region of the USA.

Recent research has evaluated the forage nutritive value of warm-season annual grasses, compared with cool-season perennial grasses and legumes, for dairy cow and horse feed under grazing $[5,6,18,19]$. Forage nutritional quality may vary across the grazing interval $[9,10]$, making it necessary to investigate these forages in cattle grazing systems on large land areas, as opposed to grazing small plot areas. Despite the high yields for cool-season annual forages demonstrated in numerous studies under nongrazing conditions with forage harvested mechanically, [20-22] graziers may be reluctant to implement alternative cool-season annual forages because of their reputation for rapidly decreasing in nutritional value as they mature [20,23-26]. Conversely, previous studies concluded that cool-season annual forages can successfully be used for livestock grazing $[6,27,28]$.

For this study, fall-planted rye (Secale cereale L.) and wheat (Triticum aestivum L.) forages were selected based on their recognized acceptance as winter cover crops in the upper Midwest of the USA due to their established adaptation to low temperatures and potential as forages for pasture. We hypothesized that the biomass yield and nutritive value of spring-grazed forages would depend on species and the day of the grazing interval. The objectives of this study were to determine the biomass yield and nutritive value of rye and wheat forages under rotational stocking conditions during the entire grazing interval duration. One season of rye and wheat was utilized for this study because the research was from a long-term rotation of cover crops and livestock grazing. Therefore, data from one forage grazing season, although limited in scope, are valuable to assess forage nutritive value for grazing livestock. The grazing land and grazing animal terminologies used in this article (e.g., "grazing interval" and "grazing season") are in accordance with the terminology defined by Allen et al. [13] on behalf of the International Forage and Grazing Lands Terminology Committee. 


\section{Materials and Methods}

\subsection{Experimental Design}

The study was carried out at the University of Minnesota West Central Research and Outreach Center in Morris, MN using organic pastureland and certified organic dairy steers (Bos taurus L.) that were born at the dairy facility, which was certified organic since 2010. For details on prestudy pastureland management, see Phillips et al. [29]. The University of Minnesota Institutional Animal Care and Use Committee approved all aspects of animal care management for this study, including handling, housing, and feeding procedures (Protocol Number: 1411-32060A).

The current study was conducted as part of a systems experiment $[30,31]$ during the cover cropping phase of a 4-year rotation, in which pastureland was rotated to either (1) rye cover crop, soybean crop (Glycine max L.), and then pastureland, or (2) wheat cover crop with fall-planted vetch (Vicia villosa Roth), corn crop (Zea mays L.), and then pastureland, as described by Galindo et al. [32]. A comprehensive description of the research location and grazing procedures is provided in Phillips et al. [29]; therefore, only a brief description is included in this article.

The treatments of rye (S. cereale) and wheat (T. aestivum) were randomly assigned to two adjacent $607 \times 66 \mathrm{~m}(4 \mathrm{ha})$ pastures (longitude $45.58^{\circ} \mathrm{N}$, latitude $95.90^{\circ} \mathrm{W}$ ) that were seeded in monoculture on 10 September 2015 at a rate of $112 \mathrm{~kg} / \mathrm{ha}$. This specific research site was selected to minimize prestudy variability between pastures, such that the slope, soil characteristics, and prestudy management of the land were similar, as described by Murison and Scott [33]. Details on prestudy soil characteristics are described by Galindo et al. [32]. The pastures were not irrigated nor fertilized.

The pastures were delineated into seven $87 \times 66 \mathrm{~m}(0.57 \mathrm{ha})$ paddocks in each of the pastures in order to implement rotational stocking methods, as shown in Figure 1. Then, each paddock was divided into three $29 \times 66 \mathrm{~m}(0.19 \mathrm{ha})$ pens to house separate groups of steers throughout the experiment. Six groups of 4 or 5 dairy steers ( 29 total steers) were randomly allocated to either treatment. The experimental units of 3 steer pens within each pasture were established and stocked with the assigned steer group. Grazing methods are reported in detail by Phillips et al. [29]. Grazing initiated when the forages in the early stem elongation growth stage reached heights of $15 \mathrm{~cm}$ above the soil, on 25 April 2016, and grazing completed after 47 days, on 10 June 2016, when forages reached the flowering stage of growth.

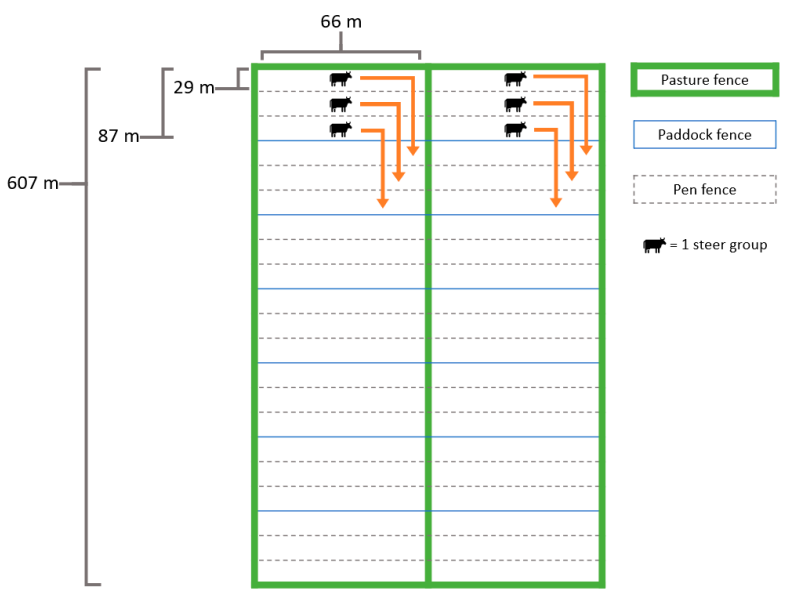

Figure 1. An illustration of the rotational stocking methods utilized during the grazing interval. The arrows depict the movement of steer groups during each rotation to a new paddock.

\subsection{Sample Collections}

Repeated sampling of wheat and rye forage was performed on every experimental unit when pens were entered for grazing by hand-harvesting random triplicate samples of 
live forage within a $0.23 \mathrm{~m}^{2}$ quadrat area to a height of $5 \mathrm{~cm}$ above the soil. These samples represented the forage available for cattle consumption. In total, 288 samples (144 per forage species) were collected throughout the study, which were immediately weighed, oven dried for $48 \mathrm{~h}$ at $60{ }^{\circ} \mathrm{C}$ in a forced-air oven, and reweighed. Dry matter forage biomass was calculated for each sample by dividing the weight of the dried sample by the area of the quadrat. All samples were then ground through a $2 \mathrm{~mm}$ screen (Model 4, Wiley Mill, Thomas Scientific, Minneapolis, MN, USA) and stored at approximately $21^{\circ} \mathrm{C}$.

\subsection{Nutritive Value Analyses}

One random sample of wheat or rye forage was selected for forage nutritive value analysis from each set of triplicate samples. A total of 96 samples (48 per forage species) were analyzed for nutritive value by a commercial laboratory (Rock River Laboratory, Watertown, WI, USA). Samples were ground through a $1 \mathrm{~mm}$ screen (Cyclone Mill, Udy Corporation, Fort Collins, CO, USA), and macronutrient compositions were measured using a near-infrared reflectance spectroscopy instrument (Model 5000, Foss, Hillerød, Denmark). The neutral detergent fiber was determined using filter bag techniques [34]. Crude protein was calculated as the percentage of nitrogen multiplied by 6.25 (method 990.03; [35]). Crude fat (CF) was determined from ether extract (method 2003.05; [36]). The value for nonfiber carbohydrates (NFC) was calculated by subtracting the available $\mathrm{CP}$ (CP minus the NDF insoluble CP), CF, NDF, and ash (analyzed using method 942.05; [37]) from 100. Total tract NDF digestibility (TTNDFD) was predicted using rumen in vitro assays described by Lopes et al. [38]. The laboratory used standardized in vitro rumen NDF digestion measures for 24, 30, and $48 \mathrm{~h} \mathrm{NDF}$ digestibility, and $240 \mathrm{~h}$ undigested NDF values to predicted TTNDFD using methods described by Goeser et al. [39].

\subsection{Statistical Analyses}

For the analysis of DM forage biomass, the triplicate samples taken on each experimental unit per sampling date were aggregated by calculating the arithmetic mean. The lmer function in the lme4 package [40] was used to determine restricted maximum likelihood (REML) estimates of the parameters in linear mixed-effects models (RStudio, Boston, MA, USA). Separate models were evaluated for each outcome with fixed factors of forage ( 2 levels), the continuous day variable (0 to 46 ), and the forage and day interaction term. Random factors were the experimental unit of steer-pen (6 levels), paddock (7 levels), and the paddock and forage interaction (14 levels). The quadratic term of the day and the interaction with forage were considered for each model. The Kenward-Roger procedure was used to estimate the denominator $\mathrm{df}$ and the statistical significance of fixed effects was declared when $p<0.05$. Predicted outcomes for rye and wheat forages for each day of the grazing period (e.g., days $0,1,2, \ldots, 46)$ were calculated using model estimates excluding the effects of random variables. Then, the bootMer function of the lme4 package was used to perform 1000 model-based parametric bootstrap resamples and construct a $95 \% \mathrm{CI}$ of the measured outcomes. The marginal $R^{2}$ value $\left(R^{2}(\mathrm{~m})\right)$ for each model was calculated to indicate the variance explained by the fixed effects of forage, day, and the interaction of forage and day using the r.squaredGLMM function of the MuMIn package [41] based on equations described by Nakagawa and Schielzeth [42]. Results are reported as predicted means and regression estimates (coefficients and $R^{2}(\mathrm{~m})$ ). Figures were created using graphic tools from the ggplot2 package [43]. Forage biomass yield results are reported as $\mathrm{Mg} / \mathrm{ha}$ on a DM basis, macronutrient composition results are reported as \% of forage DM, and TTNDFD results are reported as $\%$ of NDF.

\section{Results}

\subsection{Weather}

The University of Minnesota West Central Research and Outreach Center weather station recorded daily weather. Table 1 reports monthly ambient temperature means, precipitation, and snowfall for the 130-year long-term mean ranging from 1886 to 2016, 
and for the duration of the current study ranging from September 2015 to June 2016. The ambient temperature for the current study was similar to the long-term mean.

Table 1. Monthly weather during the study duration compared to the long-term mean.

\begin{tabular}{|c|c|c|c|c|c|c|c|c|c|c|c|}
\hline & \multicolumn{10}{|c|}{ Month } & \multirow{2}{*}{ Total } \\
\hline & September & October & November & December & January & February & March & April & May & June & \\
\hline & \multicolumn{10}{|c|}{ Temperature, ${ }^{\circ} \mathrm{C}^{\text {a }}$} & Mean \\
\hline 2015-2016 & 14 & 6 & 0 & -6 & -11 & -8 & 0 & 3 & 10 & 16 & 2 \\
\hline \multirow[t]{2}{*}{ Long-term } & 15 & 8 & -1 & -9 & -13 & -10 & -3 & 6 & 14 & 19 & 3 \\
\hline & \multicolumn{10}{|c|}{ Rainfall, $\mathrm{mm}^{\mathrm{b}}$} & Sum \\
\hline 2015-2016 & 34 & 40 & 47 & 27 & 7 & 17 & 16 & 47 & 51 & 48 & 333 \\
\hline \multirow[t]{2}{*}{ Long-term } & 59 & 47 & 25 & 17 & 18 & 18 & 30 & 58 & 76 & 102 & 447 \\
\hline & \multicolumn{10}{|c|}{ Snowfall, $\mathrm{mm}^{\mathrm{b}}$} & Sum \\
\hline 2015-2016 & 0 & 0 & 5 & 287 & 112 & 155 & 36 & 36 & 0 & 0 & 630 \\
\hline Long-term & 0 & 18 & 127 & 178 & 178 & 188 & 198 & 84 & 3 & 0 & 973 \\
\hline
\end{tabular}

Daily weather data collected from the University of Minnesota West Central Research and Outreach Center weather station in Morris, MN, during the study duration from September 2015 to June 2016 and for the long-term mean from 1886 to 2016 . $^{\text {a }}$ Ambient temperature is expressed as monthly arithmetic means. ${ }^{\mathrm{b}}$ Precipitation is expressed as monthly summations.

\subsection{Forage Biomass Yield}

Table 2 reports the regression coefficients used to predict dry matter forage biomass yield based on forage species and the day of the grazing interval. For rye, there were no apparent linear nor quadratic effects for the day variable. However, the cubic term for the day variable indicated a decreasing quadratic trend during the beginning of the grazing interval and an increasing quadratic trend during the latter part of the grazing interval.

Table 2. Regression coefficients and 95\% confidence intervals (CIs) for predicting dry matter biomass yield of fall-planted rye (Secale cereale L.) and wheat (Triticum aestivum L.) forages during the spring grazing interval from 25 April to 10 June 2016.

\begin{tabular}{|c|c|c|c|c|c|c|c|c|c|c|c|}
\hline \multirow[b]{2}{*}{$\beta_{0}$} & \multicolumn{2}{|c|}{ Rye } & \multirow[b]{2}{*}{ Dayc $_{C}$} & \multirow[b]{2}{*}{$\beta_{0}$} & \multicolumn{2}{|c|}{ Wheat } & \multicolumn{5}{|c|}{ Source of Variation $^{1}$} \\
\hline & Dayl $_{L}$ & Dayo $_{Q}$ & & & Dayl $_{L}$ & Day $_{Q}$ & Dayc $_{C}$ & $\mathbf{D}$ & F & $\mathbf{F} \times \mathbf{D}$ & $R^{2}(\mathrm{~m})$ \\
\hline & \multicolumn{6}{|c|}{ Biomass yield, $\mathrm{Mg} \mathrm{ha}^{-1}$} & \multicolumn{5}{|c|}{ Probability } \\
\hline $\begin{array}{c}2.85 \\
{[2.5,3.2]}\end{array}$ & $\begin{array}{c}-2.00 \\
{[-4.1,0.1]}\end{array}$ & $\begin{array}{c}-1.25 \\
{[-3.5,1.0]}\end{array}$ & $\begin{array}{c}4.93 \\
{[2.8,7.1]}\end{array}$ & $\begin{array}{c}2.52 \\
{[2.2,2.9]}\end{array}$ & $\begin{array}{c}6.54 \\
{[4.4,8.7]}\end{array}$ & $\begin{array}{c}0.63 \\
{[-1.8,2.9]}\end{array}$ & $\begin{array}{c}0.00 \\
{[-2.2,2.2]}\end{array}$ & 0.001 & 0.24 & $<0.0001$ & 0.37 \\
\hline
\end{tabular}

$\beta_{0}$, intercept coefficient at day 0 (25 April 2016) of the grazing interval; Day $\mathrm{L}_{\mathrm{L}}$, linear slope coefficient for day; Day, quadratic coefficient for day; Day , cubic coefficient for day. ${ }^{1} p$-values of $F$-tests where effect of day is pooled; F, forage; $\mathrm{D}$, day; $\mathrm{F} \times \mathrm{D}$, forage-day interaction; $R^{2}(\mathrm{~m})$, marginal $R^{2}$ (i.e., variance explained by fixed factors).

Predicted means for DM biomass yield of rye and wheat forages during the grazing interval are reported in Figure 2. In general, rye yielded greater forage biomass at the beginning of the grazing interval, while wheat yielded greater forage biomass in the latter part of the grazing interval. Rye tends to have greater cold hardiness than wheat, which explains rye's rapid forage growth at the beginning of the grazing interval.

\subsection{Nutritive Value}

Table 3 reports the fixed effects regression coefficients for predicting forage macronutrient compositions and TTNDFD of rye and wheat forages based on forage species and day of the grazing interval. The NDF $(\sim 46 \% \mathrm{DM})$ made up the majority of the forage composition, followed by NFC ( $26 \% \mathrm{DM}), \mathrm{CP}(\sim 18 \% \mathrm{DM})$, and CF ( $3 \% \mathrm{DM})$. The TTNDFD ranged between 35 and $71 \% \mathrm{NDF}$ over the course of the grazing interval.

\subsection{NDF and TTNDFD}

For the analysis of NDF, the fixed effects included in the model were all important predictors and explained the majority of the model variation (Figure 3). In general, the 
rye forage had greater $\mathrm{NDF}$, with the exception being during the start and end of the grazing interval. Rye had greater NDF than wheat from day 5 through day 36 of the grazing interval.

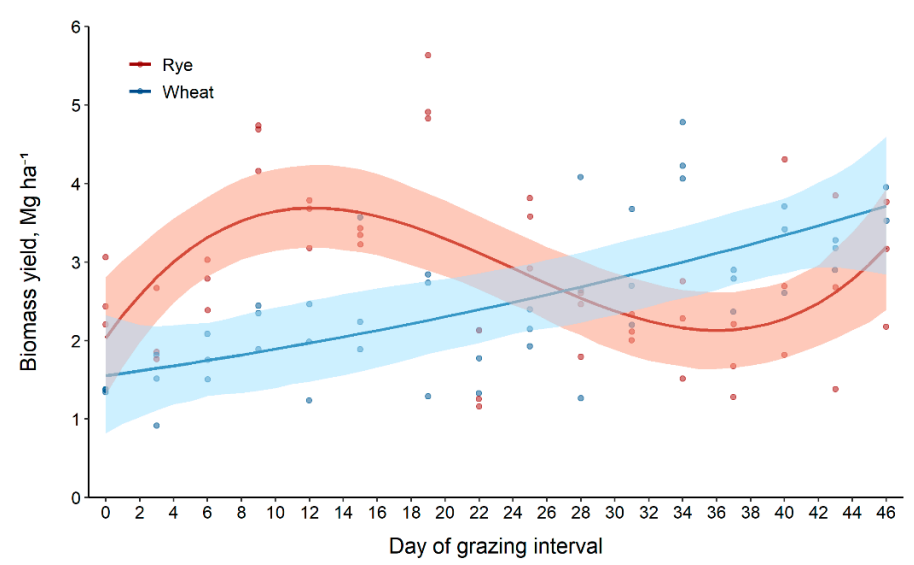

Figure 2. Scatter plot of original data with regression lines (solid lines) and bootstrap 95\% confidence intervals (transparent bands) based on 1000 resamples for dry matter biomass yield of rye and wheat forages during the grazing interval (day $0=25$ April 2016; day $46=10$ June 2016).

Table 3. Fixed effects regression coefficients and $95 \%$ confidence intervals (CI) for predicting forage nutritive value characteristics of rye (Secale cereale L.) and wheat (Triticum aestivum L.) forages during spring grazing from 25 April to 10 June 2016 .

\begin{tabular}{|c|c|c|c|c|c|c|c|c|c|c|}
\hline \multirow[b]{2}{*}{ Characteristic $^{2}$} & \multicolumn{3}{|c|}{ Rye } & \multicolumn{3}{|c|}{ Wheat } & \multicolumn{3}{|c|}{ Source of Variation ${ }^{1}$} & \multirow[b]{2}{*}{$R^{2}(\mathrm{~m})$} \\
\hline & $\beta_{0}$ & Dayl $_{L}$ & Daye $_{Q}$ & $\beta_{0}$ & $\operatorname{Day}_{L}$ & Daye $_{Q}$ & D & F & $\mathbf{F} \times \mathbf{D}$ & \\
\hline & & \multicolumn{4}{|c|}{ g $100 \mathrm{~g}^{-1}$ of dry matter } & \multicolumn{5}{|c|}{ Probability } \\
\hline $\mathrm{NDF}$ & $\begin{array}{c}48.0 \\
{[46.5,49.6]}\end{array}$ & $\begin{array}{c}42.7 \\
{[34.0,51.6]}\end{array}$ & $\begin{array}{c}-5.38 \\
{[-15.2,4.4]}\end{array}$ & $\begin{array}{c}45.2 \\
{[43.7,46.8]}\end{array}$ & $\begin{array}{c}52.1 \\
{[43.3,61.0]}\end{array}$ & $11.6[1.3,21.0]$ & $<0.0001$ & 0.04 & 0.03 & 0.68 \\
\hline NFC & $\begin{array}{c}27.7 \\
{[25.8,29.6]} \\
\end{array}$ & $\begin{array}{c}-0.105 \\
{[-0.17,-0.04]}\end{array}$ & & $\begin{array}{c}28.3 \\
{[26.4,30.2]} \\
\end{array}$ & $\begin{array}{c}-0.095 \\
{[-0.16,-0.03]}\end{array}$ & & $<0.0001$ & 0.70 & 0.82 & 0.16 \\
\hline $\mathrm{CP}$ & $\begin{array}{c}21.4 \\
{[19.7,23.1]}\end{array}$ & $\begin{array}{c}-0.172 \\
{[-0.22,-0.12]}\end{array}$ & & $\begin{array}{c}25.3 \\
{[23.6,27.0]}\end{array}$ & $\begin{array}{c}-0.267 \\
{[-0.32,-0.21]}\end{array}$ & & $<0.0001$ & 0.003 & 0.01 & 0.57 \\
\hline Crude fat & $\begin{array}{c}2.68 \\
{[2.6,2.7]}\end{array}$ & $\begin{array}{c}-2.06 \\
{[-2.5,-1.7]}\end{array}$ & $\begin{array}{c}0.822 \\
{[0.31,1.23]}\end{array}$ & $\begin{array}{c}2.41 \\
{[2.4,2.5]}\end{array}$ & $\begin{array}{c}-1.59 \\
{[-2.0,-1.2]}\end{array}$ & $\begin{array}{c}0.554 \\
{[0.15,0.98]}\end{array}$ & $<0.0001$ & 0.003 & 0.18 & 0.72 \\
\hline \multicolumn{11}{|c|}{ g $100 \mathrm{~g}^{-1}$ of NDF } \\
\hline TTNDFD & $\begin{array}{c}56.0 \\
{[53.6,58.2]}\end{array}$ & $\begin{array}{c}-75.5 \\
{[-87.0,-64.3]}\end{array}$ & $\begin{array}{c}-11.9 \\
{[-24.0,1.3]}\end{array}$ & $\begin{array}{c}55.9 \\
{[53.6,58.2]}\end{array}$ & $\begin{array}{c}-77.1 \\
{[-88.6,-65.9]}\end{array}$ & $\begin{array}{c}-19.6 \\
{[-31.7,-6.4]}\end{array}$ & $<0.0001$ & 0.99 & 0.68 & 0.75 \\
\hline
\end{tabular}

$\beta_{0}$, intercept coefficient at day 0 (25 April 2016) of the grazing interval; Day $\mathrm{L}_{\mathrm{L}}$ linear slope coefficient for day; Day, quadratic coefficient for day. ${ }^{1} p$-values of $F$-tests where effect of day is pooled for nonlinear models; $\mathrm{F}$, forage; $\mathrm{D}$, day; $\mathrm{F} \times \mathrm{D}$, forage and day interaction; $R^{2}(\mathrm{~m})$, marginal $R^{2}$ (i.e., variance explained by fixed factors). ${ }^{2} \mathrm{NDF}$, neutral detergent fiber; NFC, nonfiber carbohydrates; $\mathrm{CP}$, crude protein; TTNDFD, total tract NDF digestibility.

The TTNDFD measurement measures the extent and speed of forage fiber digestion of dairy cows that takes into account the passage rate of the forage (Figure 4). Forages had similar TTNDFD throughout the grazing interval. Forages decreased quadratically in TTNDFD over the grazing interval.

\subsection{NFC}

For the analysis of NFC, results from Table 3 indicate that the fixed effects in the model were poor predictors of NFC variation. Neither the main effect of forage nor the interaction effect between forage species and day was a useful predictor for NFC (Figure 5).

For the analysis of $\mathrm{CP}$, the fixed effects included in the model were all significant predictors, and they explained most of the model variation (Table 2). Although both forages decreased linearly in CP over the grazing interval, the linear coefficient of day 
for rye was $0.1 \%$ DM greater than that of wheat. The forage and day interaction had a significant effect; the predicted means for forages over the course of the grazing period are given in Figure 6. The forages had similar CP content.

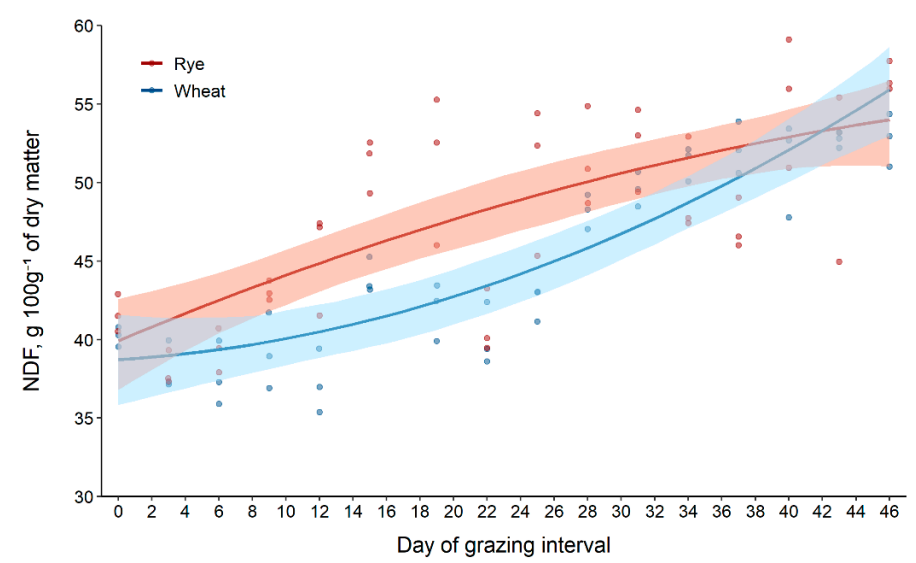

Figure 3. Scatter plot of original data with regression lines (solid lines) and bootstrap 95\% confidence intervals (transparent bands) based on 1000 resamples for NDF content of rye and wheat forages during the grazing interval (day $=25$ April 2016; day $46=10$ June 2016).

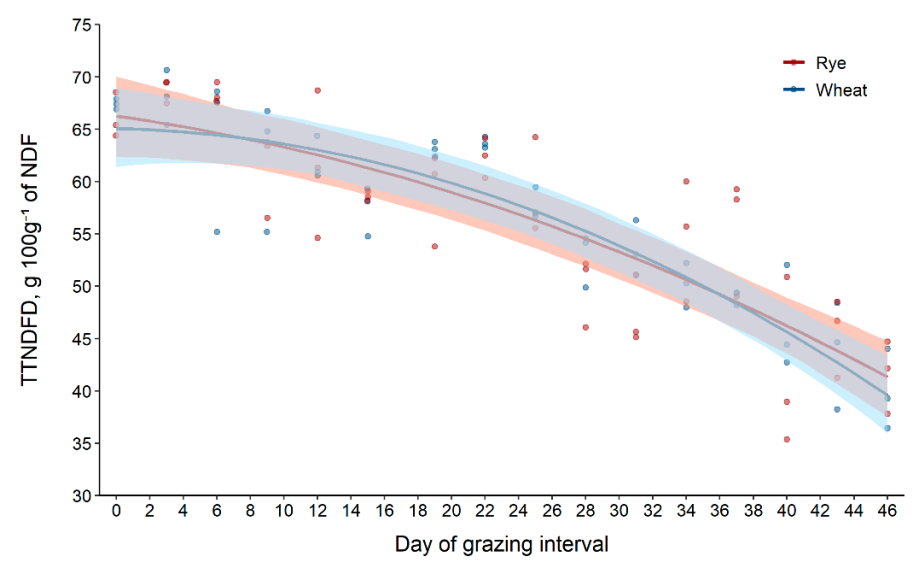

Figure 4. Scatter plot of original data with regression lines (solid lines) and bootstrap 95\% confidence intervals (transparent bands) based on 1000 resamples for total tract neutral detergent fiber digestibility (TTNDFD) content of rye and wheat forages during the grazing period (day $0=25$ April 2016; day $_{46}=10$ June 2016).

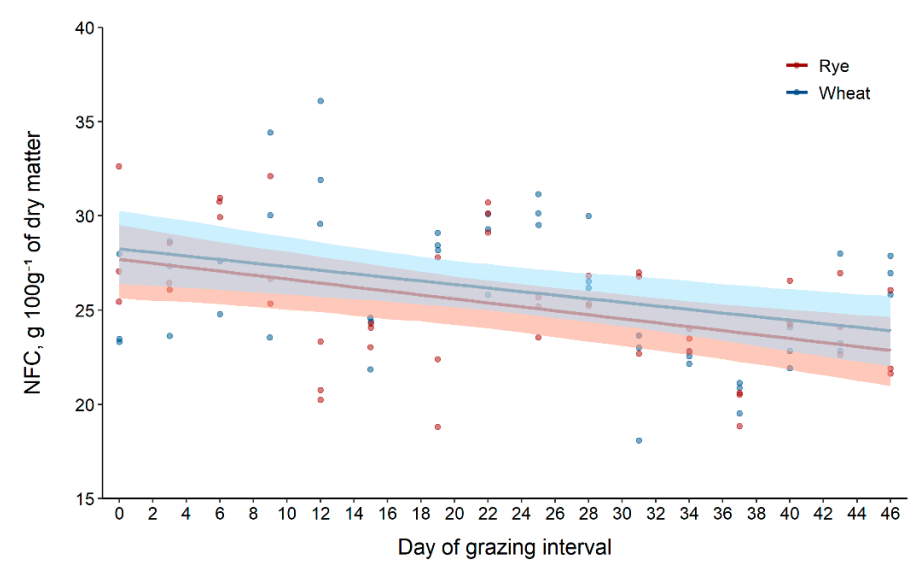

Figure 5. Scatter plot of original data with regression lines (solid lines) and bootstrap 95\% confidence intervals (transparent bands) based on 1000 resamples for nonfiber carbohydrates (NFC) content of rye and wheat forages during the grazing interval (day $0=25$ April; day $46=10$ June 2016). 


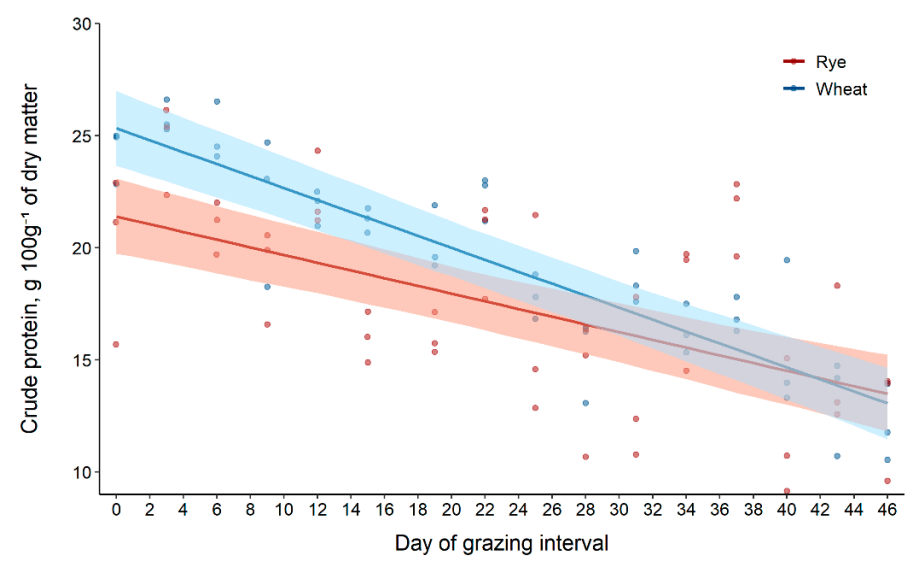

Figure 6. Scatter plot of original data with regression lines (solid lines) and bootstrap 95\% confidence intervals (transparent bands) based on 1000 resamples for crude protein content of rye and wheat forages during the grazing interval (day $=25$ April 2016; day $46=10$ June 2016).

\section{Discussion}

The biomass yield and nutritive value of winter rye and wheat from field-scale integration of crops and livestock are from a single season (see Supplementary Materials). The analyzed variables, particularly biomass, may be affected by genotype by environment interaction. Pasture management, precipitation, and temperature, soil fertility, fertilizer application, grazing rest period may influence the yield and nutritive value of forages and thus the differences observed in the current study. Although data are from a single season, farmers in the Upper Midwest of the USA are developing integrated crop-livestock systems, and the results of the study will provide guidance to farmers for selecting forages for early spring grazing of livestock.

For wheat, the biomass yield increased at a linear rate during the grazing period with no apparent quadratic nor cubic effects for the day variable. These findings are consistent with the results of previous studies that reported decreasing or sustaining forage biomass yields for rye and increasing forage biomass yields for wheat over the course of spring and summer growing intervals [22,44]. Similar to the results of the current study, Kim et al. [22] reported a cubic trend in forage biomass yield during spring growing interval for fall-planted rye and a general increase in forage biomass yield during spring growing interval for fall-planted wheat under nongrazing conditions. Lauriault and Kirksey [45] found that wheat had greater forage biomass later in the spring and summer, compared to rye.

The range of forage biomass yield observed during the study was 2.0 to $3.7 \mathrm{Mg} / \mathrm{ha}$ for rye and 1.6 to $3.7 \mathrm{Mg} / \mathrm{ha}$ for wheat, which are similar values to those reported in previous studies for fall-planted wheat and rye. Islam et al. [46] conducted a study in southeast WY investigating the spring and summer forage production of fall-planted annual small grain crops and reported a mean biomass yield for rye of $3.2 \mathrm{Mg} / \mathrm{ha}$ for spring harvested forage and $3.1 \mathrm{Mg} / \mathrm{ha}$ for summer harvested forage when averaged across varieties and years. A study conducted at the same research station as the current study in MN reported a spring forage biomass yield range of 1.4 to $4.6 \mathrm{Mg} / \mathrm{ha}$ for fall-planted rye at the stem elongation through the flowering physiological growth stages, which are similar to the growth stages of forages of the current study [47].

Both forages increased in NDF over the grazing interval, which agrees with numerous previous studies that reported an increase of NDF in annual small grain forages as plants matured $[6,26,44,48,49]$. Islam et al. [46] reported 6\% DM greater NDF for rye forage than wheat forage when averaged and compared across varieties, seasons, and years. The NDF values of the current study are slightly lower than those reported in previous studies, which may be due to less than normal precipitation during the spring grazing interval during the years of grazing at the research center in the current study. Carmi et al. [49] reported that low irrigation resulted in significantly lower NDF values, compared to high irrigation, regardless of the physiological growth stage for sorghum forage. The NDF production of 
forages in the current study may have been affected by suppressed precipitation that likely slowed maturation and decreased fiber production. Previous studies similarly reported a decrease in NDF digestibility over the growing interval for a variety of annual small grain forages [44,48].

On average, the TTNDFD of forages declined by approximately $25 \%$ NDF over the grazing interval. The cellulose and hemicellulose portions of NDF represent the digestible components of fiber that provide energy for cattle. The NDF is also comprised of lignin, which is not digestible and reduces the digestibility of other plant constituents. The model predicting TTNDFD had the highest $R^{2}(\mathrm{~m})$ value, compared to the other models predicting nutritive quality characteristics (Table 3 ). The recommended TTNDFD value for forages under cattle grazing is not well defined, but previous research and reports suggest values of $\geq 50 \%$ NDF as target goals for grazing cattle $[38,50]$. The TTNDFD predictions for forages of the current study met these recommendations from day 0 through day 33 of the grazing interval. Grazing rye and wheat forages in the vegetative growth stage is preferred to maximize the digestibility of NDF.

Both forages decreased linearly in NFC over the grazing interval. The variability in NFC was quite high. Results from a previous study that investigated the dynamic nutritive value of rye and wheat forages under grazing reported relatively stable NFC values during early vegetative stages of forage development [44]. These results are similar to those of the current study when forages in the vegetative state were grazed in the first few weeks of the grazing interval. Samples collected from day 0 to 12 of the grazing interval represent previously nongrazed forages, whereas samples collected thereafter represent regrowth of previously grazed forages. This is an important consideration in terms of explaining potential variation in grain development. The fluctuation of NFC in forage regrowth may be partially explained by selective grazing and the resulting heterogeneous regrowth of forages, where the maturity of seed development depends on whether the plant was previously defoliated or not [51].

For the majority of the grazing interval, wheat forage had greater CP. Numerous studies also agree that wheat forage has greater $\mathrm{CP}$, compared to rye forage $[25,26,46]$. The range for the observed $\mathrm{CP}$ of forages during the study was 14 to $21 \% \mathrm{DM}$ for rye and 13 to $25 \% \mathrm{DM}$ for wheat. These $\mathrm{CP}$ values are consistent with previous studies performed in the Midwest region of the USA, which reported values of 12 to $20 \%$ in rye forage $[29,51]$ and 11 to $34 \%$ in wheat forage $[6,25,52]$. The $\mathrm{CP}$ levels were well above the estimated minimum recommendation of $11 \% \mathrm{DM}$ for growing and finishing beef cattle during the entire grazing interval [53]. With regard to dairy cattle nutritional demands, the NRC [54] reported that a $\mathrm{CP}$ level of $23 \%$ maximizes milk production, which is similar to $\mathrm{CP}$ values for wheat forage during the first week of grazing. Therefore, wheat forage may be preferred for grazing lactating dairy cattle to maximize $\mathrm{CP}$ intake and subsequent milk production. Regardless of forage species, the $\mathrm{CP}$ was greatest earlier in the grazing interval.

Grazing land management is presently the main focus for organic and pasture-raised cattle producers. Fall-planted rye and wheat forages were investigated under rotational cattle grazing during the subsequent early spring through summer, which produced nutritionally valuable feed sources during the early grazing interval. Grazing seasons are especially short in the upper Midwestern regions of the USA due to freezing winter temperatures that are normally observed from November to March. Producing adequate forage biomass that is nutritionally valuable for grazing cattle is an obstacle shared by producers in similar climates. Strategies to increase forage production throughout the grazing season include methods to extend the grazing season into the early spring. Stocking cool-season annual pastures early in the grazing season has been previously suggesting as a method to extend the grazing season beyond the potential of perennial pasture systems. Furthermore, particular cool-season annual forages, such as rye and wheat, have the potential to be utilized in crop-livestock integration systems via pasture. When pastures are temporarily established, producers may benefit from the soil fertility effects of cover crops between cereal grain crop rotations while also providing cattle a nutritionally valuable 
feed source for grazing. Utilizing pastures may be an especially tactical management strategy for certified-organic producers in the USA since the NOP requires a soil building plan and for cattle to consume $\geq 30 \%$ of their dry matter intake from pasture during the grazing season.

\section{Conclusions}

Results of the current study suggest that fall-planted rye may offer more forage biomass earlier in the following spring at the expense of lower $\mathrm{CP}$, compared to wheat. Therefore, utilizing rye as a forage source for grazing may be especially useful when the primary goal is to extend the grazing season into the early spring. In general, the NDF increased over the course of the grazing interval, while the CP and TTNDFD decreased. Thus, producers should aim to stock cattle as soon as conditions are suitable for grazing to take advantage of the high nutritive value offered in immature forages. It is important to stress that applying the results of the 1-year study to the development of crop-livestock integration approaches in other agroecological zones may require some adaptation. The biomass yield and nutritional value of forages may vary in different zones based on several factors, such as climate, grazing management, irrigation, and soil fertility, as well as plant characteristics such as density, growth rates, and physiological stress. Authors encourage future studies to investigate forages intended for pastures under large-scale grazing conditions.

Supplementary Materials: The following are available online at https:/ /www.mdpi.com/article/10 $.3390 /$ crops1020006/s1, Supplementary Materials S1: biomass and quality data.

Author Contributions: Conceptualization, B.J.H. and K.D.; data curation, H.N.P.; formal analysis, H.N.P.; funding acquisition, B.J.H., K.D. and R.T.; investigation, H.N.P. and B.J.H.; methodology, B.J.H.; project administration, B.J.H.; supervision, B.J.H.; visualization, H.N.P.; writing—original draft preparation, H.N.P.; writing — review and editing, H.N.P. All authors have read and agreed to the published version of the manuscript.

Funding: This work is supported by the Organic Agriculture Research and Extension Initiative (OREI) [Grant No. 2014-51300-22541/Project Accession No. 1003975] from the USDA National Institute of Food and Agriculture.

Institutional Review Board Statement: The study was conducted according to the guidelines of the Declaration of Helsinki and approved by the Institutional Animal Care and Use Committee of University of Minnesota (protocol code 1411-32060A and approved 29 December 2014).

Informed Consent Statement: Not applicable.

Data Availability Statement: Data S1: biomass yield and nutritive quality data used for analysis.

Acknowledgments: The authors express gratitude to Darin Huot, staff, and summer interns at WCROC for their assistance in data collection and care of animals.

Conflicts of Interest: The authors declare no conflict of interest. The funders had no role in the design of the study; in the collection, analyses, or interpretation of data; in the writing of the manuscript, or in the decision to publish the results.

\section{References}

1. Greene, C.; McBride, W. Consumer demand for organic milk continues to expand-Can the US dairy sector catch up? Agric. Appl. Econ. Assoc. 2015, 30, 1-6.

2. Brummer, E.C.; Moore, K.J. Persistence of perennial cool-season grass and legume cultivars under continuous grazing by beef cattle. Agron. J. 2000, 92, 466-471. [CrossRef]

3. Kallenbach, R.L.; Bishop-Hurley, G.J.; Massie, M.D.; Kerley, M.S.; Roberts, C.A. Stockpiled annual ryegrass for winter forage in the lower Midwestern USA. Crop Sci. 2003, 43, 1414-1419. [CrossRef]

4. McCormick, J.S.; Sulc, R.M.; Barker, D.J.; Beuerlein, J.E. Yield and nutritive value of autumn-seeded winter-hardy and wintersensitive annual forages. Crop Sci. 2006, 46, 1981-1989. [CrossRef]

5. Coblentz, W.K.; Bertram, M.G.; Martin, N.P. Planting date effects on fall forage production of oat cultivars in Wisconsin. Agron. J. 2011, 103, 145-155. [CrossRef] 
6. Grev, A.M.; Sheaffer, C.C.; DeBoer, M.L.; Catalano, D.N.; Martinson, K.L. Preference, yield, and forage nutritive value of annual grasses under horse grazing. Agron. J. 2017, 109, 1561-1572. [CrossRef]

7. Sovell, L.A.; Vondracek, B.; Frost, J.A.; Mumford, K.G. Impacts of rotational grazing and riparian buffers on physicochemical and biological characteristics of Southeastern Minnesota, USA, streams. Environ. Manag. 2000, 26, 629-641. [CrossRef]

8. Oates, L.G.; Undersander, D.J.; Gratton, C.; Bell, M.M.; Jackson, R.D. Management-intensive rotational grazing enhances forage production and quality of subhumid cool-season pastures. Crop Sci. 2011, 51, 892-901. [CrossRef]

9. Hardison, W.A.; Reid, J.T.; Martin, C.M.; Woolfolk, P.G. Degree of herbage selection by grazing cattle. J. Dairy Sci. 1954, 37, 89-102. [CrossRef]

10. Barrett, P.D.; Laidlaw, A.S.; Mayne, C.S.; Christie, H. Pattern of herbage intake rate and bite dimensions of rotationally grazed dairy cows as sward height declines. Grass Forage Sci. 2001, 56, 362-373. [CrossRef]

11. Dabney, S.M.; Delgato, J.A.; Reeves, D.W. Using winter cover crops to improve soil and water quality. Commun. Soil Sci. Plant Anal. 2001, 32, 1221-1250. [CrossRef]

12. Electronic Code of Federal Regulations. Available online: https:/ / www.ecfr.gov/ (accessed on 10 May 2021).

13. Allen, V.G.; Batello, C.; Berretta, E.J.; Hodgson, J.; Kothmann, M.; Li, X.; McIvor, J.; Milne, J.; Morris, C.; Peeters, A.; et al. An international terminology for grazing lands and grazing animals. Grass Forage Sci. 2011, 66, 2-28. [CrossRef]

14. Sulc, R.M.; Tracy, B.F. Integrated crop-livestock systems in the U.S. corn belt. Agron. J. 2007, 99, 335-345. [CrossRef]

15. Jensen, J.D.; Christensen, T.; Denver, S.; Ditlevsen, K.; Lassen, J.; Teuber, R. Heterogeneity in consumers' perceptions and demand for local (organic) food products. Food Qual. Prefer. 2019, 73, 255-265. [CrossRef]

16. Hayden, J.; Rocker, S.; Phillips, H.; Heins, B.; Smith, A.; Delate, K. The importance of social support and communities of practice: Farmer perceptions of the challenges and opportunities of integrated crop-livestock systems on organically managed farms in the Northern US. Sustainability 2018, 10, 4606. [CrossRef]

17. Lemaire, G.; Franzluebbers, A.; de Carvalho, P.C.F.; Dedieu, B. Integrated crop-livestock systems: Strategies to achieve synergy between agricultural production and environmental quality. Agric. Ecosyst. Environ. 2014, 190, 4-8. [CrossRef]

18. Ritz, K.E.; Heins, B.J.; Moon, R.; Sheaffer, C.; Weyers, S.L. Forage Yield and Nutritive Value of Cool-Season and Warm-Season Forages for Grazing Organic Dairy Cattle. Agronomy 2020, 10, 1963. [CrossRef]

19. Ritz, K.E.; Heins, B.J.; Moon, R.D.; Sheaffer, C.C.; Weyers, S.L. Milk Production, Body Weight, Body Condition Score, Activity, and Rumination of Organic Dairy Cattle Grazing Two Different Pasture Systems Incorporating Cool- and Warm-Season Forages. Animals 2021, 11, 264. [CrossRef] [PubMed]

20. Cherney, J.H.; Marten, G.C. Small grain crop forage potential: I. Biological and chemical determinants of quality, and yield. Crop Sci. 1982, 22, 227-231. [CrossRef]

21. Edmisten, K.L.; Green, J.T.; Mueller, J.P.; Burns, J.C. Winter annual small grain forage potential. I. Dry matter yield in relation to morphological characteristics of four small grain species at six growth stages. Commun. Soil Sci. Plant Anal. 1998, 29, 867-879. [CrossRef]

22. Kim, K.-S.; Anderson, J.D.; Webb, S.L.; Newell, M.A.; Butler, T.J. Variation of winter forage production in four small grain species-oat, rye, triticale and wheat. Pak. J. Bot. 2017, 49, 553-559.

23. Cherney, J.H.; Marten, G.C. Small grain crop forage potential: II. Interrelationships among biological, chemical, morphological, and anatomical determinants of quality. Crop Sci. 1982, 22, 240-245. [CrossRef]

24. Edmisten, K.L.; Green, J.T.; Mueller, J.P.; Burns, J.C. Winter annual small grain forage potential. II. Quantification of nutritive characteristics of four small grain species at six growth stages. Commun. Soil Sci. Plant Anal. 1998, 29, 881-899. [CrossRef]

25. Moyer, J.L.; Coffey, K.P. Forage quality and production of small grains interseeded into bermudagrass sod or grown in monoculture. Agron. J. 2000, 92, 748-753. [CrossRef]

26. Geren, H. Dry matter yield and silage quality of some winter cereals harvested at different stages under Mediterranean climate conditions. Turk. J. Field Crop. 2014, 19, 197-202. [CrossRef]

27. McCartney, D.; Fraser, J.; Ohama, A. Annual cool season crops for grazing by beef cattle. A Canadian Review. Can. J. Anim. Sci. 2008, 88, 517-533. [CrossRef]

28. Li, Y.; Allen, V.G.; Hou, F.; Chen, J.; Brown, C.P. Steers grazing a rye cover crop influence growth of rye and no-till cotton. Agron. J. 2013, 105, 1571-1580. [CrossRef]

29. Phillips, H.N.; Heins, B.J.; Delate, K.; Turnbull, R. Fatty Acid Composition Dynamics of Rye (Secale cereale L.) and Wheat (Triticum aestivum L.) Forages under Cattle Grazing. Agronomy 2020, 10, 813. [CrossRef]

30. Phillips, H.N.; Heins, B.J.; Delate, K.; Turnbull, R. Impact of grazing dairy steers on winter rye (Secale cereale) versus winter wheat (Triticum aestivum) and effects on meat quality, fatty acid and amino acid profiles, and consumer acceptability of organic beef. PLoS ONE 2017, 12, e0187686. [CrossRef]

31. Nazareth, J.; Shaw, A.; Delate, K.; Turnbull, R. Food safety considerations in integrated organic crop-livestock systems: Prevalence of Sal. Renew. Agric. Food Syst. 2021, 36, 8-16. [CrossRef]

32. Galindo, F.S.; Delate, K.; Heins, B.; Phillips, H.; Smith, A.; Pagliari, P.H. Cropping System and Rotational Grazing Effects on Soil Fertility and Enzymatic Activity in an Integrated Organic Crop-Livestock System. Agronomy 2020, 10, 803. [CrossRef]

33. Murison, R.; Scott, J.M. Statistical methodologies for drawing causal inference from an unreplicated farmlet experiment conducted by the Cicerone Project. Anim. Prod. Sci. 2013, 53, 643-648. [CrossRef]

34. Ankom Technology. NDF Method: Method 13. Available online: https:/ / www.ankom.com/ (accessed on 10 May 2021). 
35. AOAC International. AOAC Official Method 990.03. Protein (Crude) in Animal Feed. AOAC Int. 2005. Available online: http:/ / www.eoma.aoac.org/ (accessed on 17 May 2021).

36. AOAC International. AOAC Official Method 2003.05. Crude Fat in Feeds, Cereal Grains, and Forages. AOAC Int. 2006. Available online: http:/ / www.eoma.aoac.org/ (accessed on 17 May 2021).

37. AOAC International. AOAC Official Method 942.05. Ash of Animal Feed. AOAC Int. 2008. Available online: http://www.eoma. aoac.org/ (accessed on 17 May 2021).

38. Lopes, F.; Cook, D.E.; Combs, D.K. Validation of an in vitro model for predicting rumen and total-tract fiber digestibility in dairy cows fed corn silages with different in vitro neutral detergent fiber digestibilities at 2 levels of dry matter intake. J. Dairy Sci. 2015, 98, 574-585. [CrossRef]

39. Goeser, J.P.; Hoffman, P.C.; Combs, D.K. Modification of a rumen fluid priming technique for measuring in vitro neutral detergent fiber digestibility. J. Dairy Sci. 2009, 92, 3842-3848. [CrossRef] [PubMed]

40. Bates, D.; Mächler, M.; Bolker, B.; Walker, S. Fitting linear mixed-effects models using lme4. J. Stat. Softw. 2015, 67, 1-48. [CrossRef]

41. Barton, K. MuMIn: Multi-Model Inference. Available online: https:/ / cran.r-project.org/package=MuMIn (accessed on 10 May 2021)

42. Nakagawa, S.; Schielzeth, H. A general and simple method for obtaining R2 from generalized linear mixed-effects models. Methods Ecol. Evol. 2013, 4, 133-142. [CrossRef]

43. Wickham, H. ggplot2: Elegant Graphics for Data Analysis; Springer: New York, NY, USA, 2016; ISBN 978-3-319-24277-4.

44. Keles, G.; Ates, S.; Coskun, B.; Alatas, M.S.; Isik, S. Forage yields and feeding value of small grain winter cereals for lambs. J. Sci. Food Agric. 2016, 96, 4168-4177. [CrossRef]

45. Lauriault, L.M.; Kirksey, R.E. Yield and nutritive value of irrigated winter cereal forage grass-legume intercrops in the Southern High Plains, USA. Agron. J. 2004, 96, 352-358.

46. Islam, M.A.; Obour, A.K.; Nachtman, J.J.; Baumgartner, R.E.; Saha, M.C. Small grains have forage production potential and nutritive value in Central High Plains of Wyoming. Forage Grazinglands 2013, 11, 1-10. [CrossRef]

47. Kantar, M.; Sheaffer, C.; Porter, P.; Krueger, E.; Ochsner, T.E. Growth stage influences forage yield and quality of winter rye. Forage Grazinglands 2011, 9, 1-7. [CrossRef]

48. Collar, C.; Aksland, G. Harvest stage effects on yield and quality of winter forage. In Proceedings of the 31st California Alfalfa and Forage Symposium, Modesto, CA, USA, 11-13 December 2001.

49. Carmi, A.; Aharoni, Y.; Edelstein, M.; Umiel, N.; Hagiladi, A.; Yosef, E.; Nikbachat, M.; Zenou, A.; Miron, J. Effects of irrigation and plant density on yield, composition and in vitro digestibility of a new forage sorghum variety, Tal, at two maturity stages. Anim. Feed Sci. Technol. 2006, 131, 120-132. [CrossRef]

50. Combs, D.K. TTNDFD: A new approach to evaluate forages. In Proceedings of the 2013 Cornell Nutrition Conference, Syracuse, NY, USA, 22-24 October 2013.

51. Harrison, M.T.; Evans, J.R.; Dove, H.; Moore, A.D. Dual-purpose cereals: Can the relative influences of management and environment on crop recovery and grain yield be dissected? Crop Pasture Sci. 2011, 62, 930-946. [CrossRef]

52. Holman, J.D.; Roberts, T.; Maxwell, S. 2015 Kansas winter annual forage variety trial. Kansas Agric. Exp. Stn. Res. Rep. 2016, 2 , 4. [CrossRef]

53. National Research Council. Nutrient Requirements of Beef Cattle, 8th ed.; The National Academies Press: Washington, DC, USA, 2016; ISBN 978-0-309-31702-3.

54. National Research Council. Nutrient Requirements of Dairy Cattle, 7th ed.; The National Academies Press: Washington, DC, USA, 2001; ISBN 978-0-309-06997-7. 